\title{
Glucagon receptor family in GtoPdb v.2021.3
}

Dominique Bataille ${ }^{1}$, Susan L. Chan ${ }^{2}$, Philippe Delagrange ${ }^{3}$, Daniel J. Drucker ${ }^{4}$, Burkhard Göke ${ }^{5}$, Rebecca Hills ${ }^{6}$, Kelly E. Mayo ${ }^{7}$, Laurence J. Miller ${ }^{8}$, Roberto Salvatori ${ }^{9}$ and Bernard Thorens ${ }^{10}$

1. INSERM, France

2. University of Nottingham, UK

3. Servier, France

4. University of Toronto, Canada

5. University of Hamburg, Germany

6. University of Edinburgh, UK

7. Northwestern University, USA

8. Mayo Clinic, USA

9. Johns Hopkins Hospital, USA

10. University of Lausanne, Switzerland

\begin{abstract}
The glucagon family of receptors (nomenclature as agreed by the NC-IUPHAR Subcommittee on the Glucagon receptor family [162]) are activated by the endogenous peptide (27-44 aa) hormones glucagon, glucagon-like peptide 1, glucagon-like peptide 2, glucose-dependent insulinotropic polypeptide (also known as gastric inhibitory polypeptide), GHRH and secretin. One common precursor (GCG) generates glucagon, glucagon-like peptide 1 and glucagon-like peptide 2 peptides [119]. For a recent review on the current understanding of the structures of GLP-1 and GLP$1 \mathrm{R}$, the molecular basis of their interaction, and the associated signaling events see de Graaf et al., 2016 [89].
\end{abstract}

\section{Contents}

This is a citation summary for Glucagon receptor family in the Guide to Pharmacology database (GtoPdb). It exists purely as an adjunct to the database to facilitate the recognition of citations to and from the database by citation analyzers. Readers will almost certainly want to visit the relevant sections of the database which are given here under database links.

GtoPdb is an expert-driven guide to pharmacological targets and the substances that act on them. GtoPdb is a reference work which is most usefully represented as an on-line database. As in any publication this work should be appropriately cited, and the papers it cites should also be recognized. This document provides a citation for the relevant parts of the database, and also provides a reference list for the research cited by those parts. For further details see [23].

Please note that the database version for the citations given in GtoPdb are to the most recent preceding version in which the family or its subfamilies and targets were substantially changed. The links below are to the current version. If you need to consult the cited version, rather than the most recent version, please contact the GtoPdb curators.

\section{Database links}

Glucagon receptor family

https://www.guidetopharmacology.org/GRAC/FamilyDisplayForward?familyId=29

Introduction to Glucagon receptor family

https://www.guidetopharmacology.org/GRAC/FamilyIntroductionForward?familyId=29

Receptors

GHRH receptor

https://www.guidetopharmacology.org/GRAC/ObjectDisplayForward?objectId=247

GIP receptor

https://www.guidetopharmacology.org/GRAC/ObjectDisplayForward?objectId=248 
GLP-1 receptor

https://www.guidetopharmacology.org/GRAC/ObjectDisplayForward?objectId=249

GLP-2 receptor

https://www.guidetopharmacology.org/GRAC/ObjectDisplayForward?objectId=250

glucagon receptor

https://www.guidetopharmacology.org/GRAC/ObjectDisplayForward?objectId=251

secretin receptor

https://www.guidetopharmacology.org/GRAC/ObjectDisplayForward?objectId=252

\section{References}

1. Adams EF, Symowski H, Buchfelder M and Poyner DR. (2000) A polymorphism in the growth hormone $(\mathrm{GH})$-releasing hormone (GHRH) receptor gene is associated with elevated response to GHRH by human pituitary somatotrophinomas in vitro. Biochem Biophys Res Commun 275: 336 [PMID:10944436]

2. Ahn JM, Medeiros M, Trivedi D and Hruby VJ. (2001) Development of potent glucagon antagonists: structure-activity relationship study of glycine at position 4. J Pept Res 58: 151-8 [PMID:11532074]

3. Baggio LL, Huang Q, Brown TJ and Drucker DJ. (2004) A recombinant human glucagon-like peptide (GLP)-1-albumin protein (albugon) mimics peptidergic activation of GLP-1 receptordependent pathways coupled with satiety, gastrointestinal motility, and glucose homeostasis. Diabetes 53: 2492-500 [PMID:15331566]

4. Bagnato A, Moretti C, Ohnishi J, Frajese G and Catt KJ. (1992) Expression of the growth hormone-releasing hormone gene and its peptide product in the rat ovary. Endocrinology 130: 1097-102 [PMID:1537276]

5. Barinaga M, Yamonoto G, Rivier C, Vale W, Evans R and Rosenfeld MG. (1983) Transcriptional regulation of growth hormone gene expression by growth hormone-releasing factor. Nature 306: 84-5 [PMID:6415487]

6. Baumann G and Maheshwari H. (1997) The Dwarfs of Sindh: severe growth hormone (GH) deficiency caused by a mutation in the GH-releasing hormone receptor gene. Acta Paediatr Suppl 423: 33-8 [PMID:9401536]

7. Bayliss WM and Starling EH. (1902) On the causation of the so-called 'peripheral reflex secretion' of the pancreas. Proc R Soc Lond, B, Biol Sci 69: 352-353

8. Beak SA, Small CJ, Ilovaiskaia I, Hurley JD, Ghatei MA, Bloom SR and Smith DM. (1996) Glucagon-like peptide-1 (GLP-1) releases thyrotropin (TSH): characterization of binding sites for GLP-1 on alpha-TSH cells. Endocrinology 137: 4130-8 [PMID:8828468]

9. Beinborn M, Worrall CI, McBride EW and Kopin AS. (2005) A human glucagon-like peptide-1 receptor polymorphism results in reduced agonist responsiveness. Regul Pept 130: 1-6 [PMID:15975668]

10. Bell GI, Sanchez-Pescador R, Laybourn PJ and Najarian RC. (1983) Exon duplication and divergence in the human preproglucagon gene. Nature 304: 368-71 [PMID:6877358]

11. Bell GI, Santerre RF and Mullenbach GT. (1983) Hamster preproglucagon contains the sequence of glucagon and two related peptides. Nature 302: 716-718 [PMID:6835407]

12. Berry SA and Pescovitz OH. (1988) Identification of a rat GHRH-like substance and its messenger RNA in rat testis. Endocrinology 123: 661-3 [PMID:3133203]

13. Billestrup N and Vale W. (1986) Growth hormone-releasing factor stimulates proliferation of somatotrophsin vitro. Proc Natl Acad Sci USA 83: 6854-6857 [PMID:3018748]

14. Bode HP, Moormann B, Dabew R and Göke B. (1999) Glucagon-like peptide 1 elevates cytosolic calcium in pancreatic beta-cells independently of protein kinase A. Endocrinology 140: 3919-27 [PMID:10465260]

15. Boisvert C, Paré C, Veyrat-Durebex C, Robert A, Dubuisson S, Morel G and Gaudreau P. (2002) Localization and regulation of a functional GHRH receptor in the rat renal medulla.

Endocrinology 143: 1475-84 [PMID:11897706]

16. Bollag RJ, Zhong Q, Phillips P, Min L, Zhong L, Cameron R, Mulloy AL, Rasmussen H, Qin F, Ding KH and Isales CM. (2000) Osteoblast-derived cells express functional glucose-dependent insulinotropic peptide receptors. Endocrinology 141: 1228-1235 [PMID:10698200]

17. Boulanger L, Girard N, Strecko J and Gaudreau P. (2002) Characterization of a growth hormonereleasing hormone binding site in the rat renal medulla. Peptides 23: 43-50 [PMID:11814616]

18. Boushey RP, Yusta B and Drucker DJ. (1999) Glucagon-like peptide 2 decreases mortality and reduces the severity of indomethacin-induced murine enteritis. Am J Physiol 277: E937-47 [PMID:10567023]

19. Breyer PR, Rothrock JK, Beaudry N and Pescovitz OH. (1996) A novel peptide from the growth hormone releasing hormone gene stimulates Sertoli cell activity. Endocrinology 137: 2159-62 [PMID:8612561]

20. Brubaker PL, Izzo A, Hill M and Drucker DJ. (1997) Intestinal function in mice with small bowel 
growth induced by glucagon-like peptide-2. Am J Physiol 272: E1050-8 [PMID:9227451]

21. Buchholz S, Schally AV, Engel JB, Hohla F, Heinrich E, Koester F, Varga JL and Halmos G. (2007) Potentiation of mammary cancer inhibition by combination of antagonists of growth hormone-releasing hormone with docetaxel. Proc Natl Acad Sci USA 104: 1943-6 [PMID:17261802]

22. Bullock BP, Heller RS and Habener JF. (1996) Tissue distribution of messenger ribonucleic acid encoding the rat glucagon-like peptide-1 receptor. Endocrinology 137: 2968-78 [PMID:8770921]

23. Buneman P, Christie G, Davies JA, Dimitrellou R, Harding SD, Pawson AJ, Sharman JL and Wu Y. (2020) Why data citation isn't working, and what to do about it Database 2020 [PMID:32367113]

24. Bunnett NW. (1994) Gastrin-releasing peptide. In Gut Peptides Edited by Walsh JH, Dockray GJ: Raven Press: 423-445 [ISBN: 0781701155]

25. Burcelin R, Li J and Charron MJ. (1995) Cloning and sequence analysis of the murine glucagon receptor-encoding gene. Gene 164: 305-10 [PMID:7590348]

26. Busto R, Schally AV, Braczkowski R, Plonowski A, Krupa M, Groot K, Armatis P and Varga JL. (2002) Expression of mRNA for growth hormone-releasing hormone and splice variants of GHRH receptors in human malignant bone tumors. Regul Pept 108: 47-53 [PMID:12220726]

27. CAHILL Jr GF, EARLE AS and ZOTTU S. (1957) In vivo effects of glucagon on hepatic glycogen, phosphorylase and glucose-6-phosphatase. Endocrinology 60: 265-9 [PMID:13397492]

28. Cai R, Schally AV, Cui T, Szalontay L, Halmos G, Sha W, Kovacs M, Jaszberenyi M, He J and Rick FG et al.. (2014) Synthesis of new potent agonistic analogs of growth hormone-releasing hormone (GHRH) and evaluation of their endocrine and cardiac activities. Peptides 52: 104-12 [PMID:24373935]

29. Campbell RM and Scanes CG. (1992) Evolution of the growth hormone-releasing factor (GRF) family of peptides. Growth Regul 2: 175-91 [PMID:1290954]

30. Campos RV, Lee YC and Drucker DJ. (1994) Divergent tissue-specific and developmental expression of receptors for glucagon and glucagon-like peptide-1 in the mouse. Endocrinology 134: 2156-64 [PMID:8156917]

31. Canonico PL, Cronin MJ, Thorner MO and MacLeod RM. (1983) Human pancreatic GRF stimulates phosphatidylinositol labeling in cultured anterior pituitary cells. Am J Physiol 245: E587-90 [PMID:6140852]

32. Carakushansky M, Whatmore AJ, Clayton PE, Shalet SM, Gleeson HK, Price DA, Levine MA and Salvatori R. (2003) A new missense mutation in the growth hormone-releasing hormone receptor gene in familial isolated GH deficiency. Eur J Endocrinol 148: 25-30 [PMID:12534354]

33. Carlquist $M$ and Johansson C. (1985) Human secretin is not identical to the porcine/bovine hormone. IRCS Med Sci 13: 217-218

34. Carlquist M, Jörnvall $\mathrm{H}$ and Mutt V. (1981) Isolation and amino acid sequence of bovine secretin. FEBS Lett 127: 71-4 [PMID:7250377]

35. Cascieri MA, Koch GE, Ber E, Sadowski SJ, Louizides D, de Laszlo SE, Hacker C, Hagmann WK, MacCoss M and Chicchi GG et al.. (1999) Characterization of a novel, non-peptidyl antagonist of the human glucagon receptor. J Biol Chem 274: 8694-7 [PMID:10085108]

36. Cervini LA, Donaldson CJ, Koerber SC, Vale WW and Rivier JE. (1998) Human growth hormonereleasing hormone hGHRH(1-29)-NH2: systematic structure-activity relationship studies. J Med Chem 41: 717-27 [PMID:9513600]

37. Chance WT, Foley-Nelson T, Thomas I and Balasubramaniam A. (1997) Prevention of parenteral nutrition-induced gut hypoplasia by coinfusion of glucagon-like peptide-2. Am J Physiol 273: G559-63 [PMID:9277438]

38. Cheeseman CI and Tsang R. (1996) The effect of GIP and glucagon-like peptides on intestinal basolateral membrane hexose transport. Am J Physiol 271: G477-82 [PMID:8843773]

39. Chen C, Vincent JD and Clarke IJ. (1994) Ion channels and the signal transduction pathways in the regulation of growth hormone secretion. Trends Endocrinol Metab 5: 227-33 [PMID:18407212]

40. Chow BK. (1995) Molecular cloning and functional characterization of a human secretin receptor. Biochem Biophys Res Commun 212: 204-11 [PMID:7612008]

41. Chow BK, Cheung KH, Tsang EM, Leung MC, Lee SM and Wong PY. (2004) Secretin controls anion secretion in the rat epididymis in an autocrine/paracrine fashion. Biol Reprod 70: 1594-9 [PMID:14749298]

42. Christopoulos A, Christopoulos G, Morfis M, Udawela M, Laburthe M, Couvineau A, Kuwasako K, Tilakaratne N and Sexton PM. (2003) Novel receptor partners and function of receptor activity-modifying proteins. J Biol Chem 278: 3293-7 [PMID:12446722]

43. Ciampani T, Fabbri A, Isidori A and Dufau ML. (1992) Growth hormone-releasing hormone is produced by rat Leydig cell in culture and acts as a positive regulator of Leydig cell function. Endocrinology 131: 2785-92 [PMID:1332849]

44. Coskun T, Sloop KW, Loghin C, Alsina-Fernandez J, Urva S, Bokvist KB, Cui X, Briere DA, Cabrera O and Roell WC et al.. (2018) LY3298176, a novel dual GIP and GLP-1 receptor agonist 
for the treatment of type 2 diabetes mellitus: From discovery to clinical proof of concept. Mol Metab 18: 3-14 [PMID:30473097]

45. Coy DH, Jiang NY, Fuselier J and Murphy WA. (1996) Structural simplification of potent growth hormone-releasing hormone analogs: implications for other members of the VIP/GHRH/PACAP family. Ann N Y Acad Sci 805: 149-58 [PMID:8993400]

46. Dalle S, Smith P, Blache P, Le-Nguyen D, Le Brigand L, Bergeron F, Ashcroft FM and Bataille D. (1999) Miniglucagon (glucagon 19-29), a potent and efficient inhibitor of secretagogue-induced insulin release through a Ca2+ pathway. J Biol Chem 274: 10869-76 [PMID:10196164]

47. Davis RJ, Page KJ, Dos Santos Cruz GJ, Harmer DW, Munday PW, Williams SJ, Picot J, Evans TJ, Sheldrick RL and Coleman RA et al.. (2004) Expression and functions of the duodenal peptide secretin and its receptor in human lung. Am J Respir Cell Mol Biol 31: 302-8 [PMID:15191914]

48. Deacon CF, Plamboeck A, Rosenkilde MM, de Heer J and Holst JJ. (2006) GIP-(3-42) does not antagonize insulinotropic effects of GIP at physiological concentrations. Am J Physiol Endocrinol Metab 291: E468-75 [PMID:16608883]

49. DeAlmeida VI and Mayo KE. (1998) Identification of binding domains of the growth hormonereleasing hormone receptor by analysis of mutant and chimeric receptor proteins. $\mathrm{Mol}$ Endocrinol 12: 750-65 [PMID:9605937]

50. Dillon JS, Tanizawa Y, Wheeler MB, Leng XH, Ligon BB, Rabin DU, Yoo-Warren H, Permutt MA and Boyd AE. (1993) Cloning and functional expression of the human glucagon-like peptide-1 (GLP-1) receptor. Endocrinology 133: 1907-10 [PMID:8404634]

51. Dong M, Wang Y, Hadac EM, Pinon DI, Holicky E and Miller LJ. (1999) Identification of an interaction between residue 6 of the natural peptide ligand and a distinct residue within the amino-terminal tail of the secretin receptor. J Biol Chem 274: 19161-7 [PMID:10383421]

52. Drucker DJ. (1998) Glucagon-like peptides. Diabetes 47: 159-69 [PMID:9519708]

53. Drucker DJ and Brubaker PL. (1996) Induction of intestinal epithelial proliferation by glucagonlike peptide 2. Proc Natl Acad Sci USA 93: 7911-7916 [PMID:8755576]

54. Drucker DJ, DeForest L and Brubaker PL. (1997) Intestinal response to growth factors administered alone or in combination with human [Gly2]glucagon-like peptide 2. Am J Physiol 273: G1252-62 [PMID:9435550]

55. Drucker DJ, Philippe J, Mojsov S, Chick WL and Habener JF. (1987) Glucagon-like peptide I stimulates insulin gene expression and increases cyclic AMP levels in a rat islet cell line. Proc Natl Acad Sci USA 84: 3434-8 [PMID:3033647]

56. Duffy JL, Kirk BA, Konteatis Z, Campbell EL, Liang R, Brady EJ, Candelore MR, Ding VD, Jiang G and Liu F et al.. (2005) Discovery and investigation of a novel class of thiophene-derived antagonists of the human glucagon receptor. Bioorg Med Chem Lett 15: 1401-5 [PMID:15713396]

57. Dunphy JL, Taylor RG and Fuller PJ. (1998) Tissue distribution of rat glucagon receptor and GLP-1 receptor gene expression. Mol Cell Endocrinol 141: 179-86 [PMID:9723898]

58. During MJ, Cao L, Zuzga DS, Francis JS, Fitzsimons HL, Jiao X, Bland RJ, Klugmann M, Banks WA and Drucker DJ et al.. (2003) Glucagon-like peptide-1 receptor is involved in learning and neuroprotection. Nat Med 9: 1173-9 [PMID:12925848]

59. Ehses JA, Lee SS, Pederson RA and McIntosh CH. (2001) A new pathway for glucose-dependent insulinotropic polypeptide (GIP) receptor signaling: evidence for the involvement of phospholipase A2 in GIP-stimulated insulin secretion. J Biol Chem 276: 23667-73 [PMID:11323439]

60. Eicher EM and Beamer WG. (1976) Inherited ateliotic dwarfism in mice. Characteristics of the mutation, little, on chromosome 6. J Hered 67: 87-91 [PMID:1270792]

61. Escobar DC, Vicentini LM, Ghigo E, Ciccarelli E, Usellini L, Capella C and Cocchi D. (1986) Growth hormone-releasing factor does not stimulate phosphoinositides breakdown in primary cultures of rat and human pituitary cells. Acta Endocrinol 112: 345-50 [PMID:3019052]

62. Exton JH and Park CR. (1966) The stimulation of gluconeogenesis from lactate by epinephrine, glucagon and cyclic 3í-5í-adenylate in the perfused rat liver. Pharmacol Rev 18: 181-188 [PMID:5904135]

63. Fan H, Gong N, Li TF, Ma AN, Wu XY, Wang MW and Wang YX. (2015) The non-peptide GLP-1 receptor agonist WB4-24 blocks inflammatory nociception by stimulating $\beta$-endorphin release from spinal microglia. Br J Pharmacol 172: 64-79 [PMID:25176008]

64. Fehmann HC, Göke R and Göke B. (1995) Cell and molecular biology of the incretin hormones glucagon-like peptide-I and glucose-dependent insulin releasing polypeptide. Endocr Rev 16: 390-410 [PMID:7671853]

65. Fehmann HC and Habener JF. (1992) Insulinotropic hormone glucagon-like peptide-I(7-37) stimulation of proinsulin gene expression and proinsulin biosynthesis in insulinoma beta TC-1 cells. Endocrinology 130: 159-66 [PMID:1309325]

66. Fehmann HC and Habener JF. (1991) Functional receptors for the insulinotropic hormone glucagon-like peptide-I(7-37) on a somatostatin secreting cell line. FEBS Lett 279: 335-40 [PMID:1672112] 
67. French MB, Lussier BT, Moor BC and Kraicer J. (1990) Effect of growth hormone-releasing factor on phosphoinositide hydrolysis in somatotrophs. Mol Cell Endocrinol 72: 221-6 [PMID:1963157]

68. Frohman LA, Downs TR, Heimer EP and Felix AM. (1989) Dipeptidylpeptidase IV and trypsinlike enzymatic degradation of human growth hormone-releasing hormone in plasma. J Clin Invest 83: 1533-40 [PMID:2565342]

69. Frohman LA and Jansson JO. (1986) Growth hormone-releasing hormone. Endocr Rev 7: 223-53 [PMID:2874984]

70. Frohman LA and Szabo M. (1981) Ectopic production of growth hormone-releasing factor by carcinoid and pancreatic islet tumors associated with acromegaly. Prog Clin Biol Res 74: 259-71 [PMID:6275403]

71. Frohman MA, Downs TR, Chomczynski P and Frohman LA. (1989) Cloning and characterization of mouse growth hormone-releasing hormone (GRH) complementary DNA: increased GRH messenger RNA levels in the growth hormone-deficient lit/lit mouse. Mol Endocrinol 3: 1529-36 [PMID:2481813]

72. Göke R and Conlon JM. (1988) Receptors for glucagon-like peptide-1(736) amide on rat insulinoma-derived cells. J Endocrinol 116: 357-362 [PMID:2832504]

73. Göke R and Göke B. (1994) Glycosylation of the GLP-1 receptor is a prerequisite for regular receptor function. Peptides 15: 675-681 [PMID:7937345]

74. Galehshahi FS, Göke B and Lankat-Buttgereit B. (1998) Contribution of a PS1-like element to the tissue- and cell-specific expression of the human GLP-1 receptor gene. FEBS Lett 436: 163-8 [PMID:9781671]

75. Gallwitz B, Witt M, Morys-Wortmann C, Fölsch UR and Schmidt WE. (1996) GLP-1/GIP chimeric peptides define the structural requirements for specific ligand-receptor interaction of GLP-1. Regul Pept 63: 17-22 [PMID:8795084]

76. Ganguli SC, Park CG, Holtmann MH, Hadac EM, Kenakin TP and Miller LJ. (1998) Protean effects of a natural peptide agonist of the $\mathrm{G}$ protein-coupled secretin receptor demonstrated by receptor mutagenesis. J Pharmacol Exp Ther 286: 593-8 [PMID:9694908]

77. Gaudreau P, Boulanger L and Abribat T. (1992) Affinity of human growth hormone-releasing factor (1-29)NH2 analogues for GRF binding sites in rat adenopituitary. J Med Chem 35: 1864-9 [PMID:1534126]

78. Gault VA, O'Harte FP, Harriott P, Mooney MH, Green BD and Flatt PR. (2003) Effects of the novel (Pro3)GIP antagonist and exendin(9-39)amide on GIP- and GLP-1-induced cyclic AMP generation, insulin secretion and postprandial insulin release in obese diabetic (ob/ob) mice: evidence that GIP is the major physiological incretin. Diabetologia 46: 222-30 [PMID:12627321]

79. Gaylinn BD. (1999) Molecular and cell biology of the growth hormone-releasing hormone receptor. Growth Horm IGF Res 9: 37-44 [PMID:10429879]

80. Gaylinn BD, Dealmeida VI, Lyons Jr CE, Wu KC, Mayo KE and Thorner MO. (1999) The mutant growth hormone-releasing hormone (GHRH) receptor of the little mouse does not bind GHRH. Endocrinology 140: 5066-74 [PMID:10537133]

81. Gaylinn BD, Harrison JK, Zysk JR, Lyons CE, Lynch KR and Thorner MO. (1993) Molecular cloning and expression of a human anterior pituitary receptor for growth hormone-releasing hormone. Mol Endocrinol 7: 77-84 [PMID:7680413]

82. Gaylinn BD, von Kap-Herr C, Golden WL and Thorner MO. (1994) Assignment of the human growth hormone-releasing hormone receptor gene (GHRHR) to 7p14 by in situ hybridization. Genomics 19: 193-5 [PMID:8188233]

83. Gelling RW, Coy DH, Pederson RA, Wheeler MB, Hinke S, Kwan T and McIntosh CH. (1997) GIP(6-30amide) contains the high affinity binding region of GIP and is a potent inhibitor of GIP142 action in vitro. Regul Pept 69: 151-4 [PMID:9226399]

84. Gelling RW, Du XQ, Dichmann DS, Romer J, Huang H, Cui L, Obici S, Tang B, Holst JJ and Fledelius C et al.. (2003) Lower blood glucose, hyperglucagonemia, and pancreatic alpha cell hyperplasia in glucagon receptor knockout mice. Proc Natl Acad Sci USA 100: 1438-43 [PMID:12552113]

85. Gick GG, Zeytin FN, Brazeau P, Ling NC, Esch FS and Bancroft C. (1984) Growth hormonereleasing factor regulates growth hormone mRNA in primary cultures of rat pituitary cells. Proc Natl Acad Sci USA 81: 1553-5 [PMID:6424119]

86. Godfrey P, Rahal JO, Beamer WG, Copeland NG, Jenkins NA and Mayo KE. (1993) GHRH receptor of little mice contains a missense mutation in the extracellular domain that disrupts receptor function. Nat Genet 4: 227-32 [PMID:8395283]

87. Gossen D, Vandermeers A, Vandermeers-Piret MC, Rathé J, Cauvin A, Robberecht P and Christophe J. (1989) Isolation and primary structure of rat secretin. Biochem Biophys Res Commun 160: 862-7 [PMID:2719704]

88. Gourlet P, Vandermeers A, Vertongen P, Rathe J, De Neef P, Cnudde J, Waelbroeck M and Robberecht P. (1997) Development of high affinity selective VIP1 receptor agonists. Peptides 18: 1539-45 [PMID:9437714] 
89. Graaf Cd, Donnelly D, Wootten D, Lau J, Sexton PM, Miller LJ, Ahn JM, Liao J, Fletcher MM and Yang D et al.. (2016) Glucagon-Like Peptide-1 and Its Class B G Protein-Coupled Receptors: A Long March to Therapeutic Successes. Pharmacol Rev 68: 954-1013 [PMID:27630114]

90. Graziano MP and Strader CD. (1993) Cloning and functional expression of a human glucagonlike peptide-1 receptor. Biochem Biophys Res Commun 196: 141-146 [PMID:8216285]

91. Gromada J, Rorsman P, Dissing S and Wulff BS. (1995) Stimulation of cloned human glucagonlike peptide 1 receptor expressed in HEK 293 cells induces cAMP-dependent activation of calcium-induced calcium release. FEBS Lett 373: 182-6 [PMID:7589461]

92. Gros L, Demiprence E, Bataille D and Kervra A. (1992) Characterization of high affinity receptors for glucagon-like peptide-1 (7-36) amide on a somatostatin-secreting cell line. Biomed Res 13: 143-150

93. Gros R, You X, Baggio LL, Kabir MG, Sadi AM, Mungrue IN, Parker TG, Huang Q, Drucker DJ and Husain M. (2003) Cardiac function in mice lacking the glucagon-like peptide-1 receptor. Endocrinology 144: 2242-52 [PMID:12746281]

94. Gubler U, Monahan JJ, Lomedico PT, Bhatt RS, Collier KJ, Hoffman BJ, Böhlen P, Esch F, Ling N and Zeytin F et al.. (1983) Cloning and sequence analysis of cDNA for the precursor of human growth hormone-releasing factor, somatocrinin. Proc Natl Acad Sci USA 80: 4311-4 [PMID:6192430]

95. Guillemin R, Brazeau P, Böhlen P, Esch F, Ling N and Wehrenberg WB. (1982) Growth hormonereleasing factor from a human pancreatic tumor that caused acromegaly. Science 218: 585-7 [PMID:6812220]

96. Gutzwiller JP, Drewe J, Göke B, Schmidt H, Rohrer B, Lareida J and Beglinger C. (1999) Glucagon-like peptide-1 promotes satiety and reduces food intake in patients with diabetes mellitus type 2. Am J Physiol 276: R1541-4 [PMID:10233049]

97. Göke B, Leferink J, Göke R and Adler G. (1989) Effect of a low-molecular weight serine proteinase inhibitor (camostate) on amylase release from isolated pancreatic acini. Res Exp Med (Berl.) 189: 33-8 [PMID:2469115]

98. Göke R, Cole T and Conlon JM. (1989) Characterization of the receptor for glucagon-like peptide-1(7-36)amide on plasma membranes from rat insulinoma-derived cells by covalent crosslinking. J Mol Endocrinol 2: 93-8 [PMID:2550026]

99. Göke R, Fehmann HC, Linn T, Schmidt H, Krause M, Eng J and Göke B. (1993) Exendin-4 is a high potency agonist and truncated exendin-(9-39)-amide an antagonist at the glucagon-like peptide 1-(7-36)-amide receptor of insulin-secreting beta-cells. J Biol Chem 268: 19650-5 [PMID:8396143]

100. Göke R, Larsen PJ, Mikkelsen JD and Sheikh SP. (1995) Identification of specific binding sites for glucagon-like peptide-1 on the posterior lobe of the rat pituitary. Neuroendocrinology 62: 130-4 [PMID:8584112]

101. Göke R, Oltmer B, Sheikh SP and Göke B. (1992) Solubilization of active GLP-1 (7-36)amide receptors from RINm5F plasma membranes. FEBS Lett 300: 232-6 [PMID:1313374]

102. Haffar BM, Hocart SJ, Coy DH, Mantey S, Chiang HC and Jensen RT. (1991) Reduced peptide bond pseudopeptide analogues of secretin. A new class of secretin receptor antagonists. J Biol Chem 266: 316-22 [PMID:1702423]

103. Hager J, Hansen L, Vaisse C, Vionnet N, Philippi A, Poller W, Velho G, Carcassi C, Contu L and Julier C et al.. (1995) A missense mutation in the glucagon receptor gene is associated with noninsulin-dependent diabetes mellitus. Nat Genet 9: 299-304 [PMID:7773293]

104. Hammer RE, Brinster RL, Rosenfeld MG, Evans RM and Mayo KE. (1985) Expression of human growth hormone-releasing factor in transgenic mice results in increased somatic growth. Nature 315: 413-6 [PMID:3923368]

105. Hansen AB, Gespach CP, Rosselin GE and Holst JJ. (1988) Effect of truncated glucagon-like peptide 1 on cAMP in rat gastric glands and HGT-1 human gastric cancer cells. FEBS Lett 236: 119-22 [PMID:2841160]

106. Hansen LH, Abrahamsen N and Nishimura E. (1995) Glucagon receptor mRNA distribution in rat tissues. Peptides 16: 1163-6 [PMID:8532603]

107. Hansen LS, Sparre-Ulrich AH, Christensen M, Knop FK, Hartmann B, Holst JJ and Rosenkilde MM. (2016) N-terminally and C-terminally truncated forms of glucose-dependent insulinotropic polypeptide are high-affinity competitive antagonists of the human GIP receptor. Br J Pharmacol 173: 826-38 [PMID:26572091]

108. Hargrove DM, Alagarsamy S, Croston G, Laporte R, Qi S, Srinivasan K, Sueiras-Diaz J, Wiśniewski K, Hartwig J and Lu M et al.. (2020) Pharmacological Characterization of Apraglutide, a Novel Long-Acting Peptidic Glucagon-Like Peptide-2 Agonist, for the Treatment of Short Bowel Syndrome. J Pharmacol Exp Ther 373: 193-203 [PMID:32075870]

109. Hashimoto K, Koga M, Motomura T, Kasayama S, Kouhara H, Ohnishi T, Arita N, Hayakawa T, Sato B and Kishimoto T. (1995) Identification of alternatively spliced messenger ribonucleic acid encoding truncated growth hormone-releasing hormone receptor in human pituitary adenomas. J Clin Endocrinol Metab 80: 2933-9 [PMID:7559877] 
110. Hassan HA, Hsiung HM, Zhang XY, Smith DP, Smiley DL and Heiman ML. (1995) Characterization of growth hormone-releasing hormone (GHRH) binding to cloned porcine GHRH receptor. Peptides 16: 1469-73 [PMID:8745060]

111. Hatton TW, Yip CC and Vranic M. (1985) Biosynthesis of glucagon (IRG3500) in canine gastric mucosa. Diabetes 34: 38-46 [PMID:3880548]

112. Heinrich G, Gros P, Lund PK, Bentley RC and Habener JF. (1984) Pre-proglucagon messenger ribonucleic acid: nucleotide and encoded amino acid sequences of the rat pancreatic complementary deoxyribonucleic acid. Endocrinology 115: 2176-81 [PMID:6548696]

113. Holl RW, Thorner MO and Leong DA. (1988) Intracellular calcium concentration and growth hormone secretion in individual somatotropes: effects of growth hormone-releasing factor and somatostatin. Endocrinology 122: 2927-32 [PMID:2453353]

114. Holtmann MH, Hadac EM, Ulrich CD and Miller LJ. (1996) Molecular basis and species specificity of high affinity binding of vasoactive intestinal polypeptide by the rat secretin receptor. J Pharmacol Exp Ther 279: 555-60 [PMID:8930157]

115. Holz 4th GG, Leech CA and Habener JF. (1995) Activation of a cAMP-regulated $\mathrm{Ca}(2+)$-signaling pathway in pancreatic beta-cells by the insulinotropic hormone glucagon-like peptide-1. J Biol Chem 270: 17749-57 [PMID:7543091]

116. Holz GG and Habener JF. (1993) Pancreatic $\beta$-cells are rendered glucose-competent by the insulinotropic hormone glucagon-like peptide-1(7-37). Nature 361: 362-365 [PMID:8381211]

117. Horváth JE, Zarándi M, Groot K and Schally AV. (1995) Effect of long-acting antagonists of growth hormone (GH)-releasing hormone on GH and cyclic adenosine 3',5'-monophosphate release in superfused rat pituitary cells. Endocrinology 136: 3849-55 [PMID:7649091]

118. Hsiung HM, Smith DP, Zhang XY, Bennett T, Rosteck Jr PR and Lai MH. (1993) Structure and functional expression of a complementary DNA for porcine growth hormone-releasing hormone receptor. Neuropeptides 25: 1-10 [PMID:8413847]

119. Irwin DM. (2001) Molecular evolution of proglucagon. Regul Pept 98: 1-12 [PMID:11179772]

120. Ishihara T, Nakamura S, Kaziro Y, Takahashi T, Takahashi K and Nagata S. (1991) Molecular cloning and expression of a cDNA encoding the secretin receptor. EMBO J 10: 1635-41 [PMID:1646711]

121. Jazayeri A, Doré AS, Lamb D, Krishnamurthy H, Southall SM, Baig AH, Bortolato A, Koglin M, Robertson NJ and Errey JC et al.. (2016) Extra-helical binding site of a glucagon receptor antagonist. Nature 533: 274-7 [PMID:27111510]

122. Jazayeri A, Rappas M, Brown AJH, Kean J, Errey JC, Robertson NJ, Fiez-Vandal C, Andrews SP, Congreve M and Bortolato A et al.. (2017) Crystal structure of the GLP-1 receptor bound to a peptide agonist. Nature 546: 254-258 [PMID:28562585]

123. Jelinek LJ, Lok S, Rosenberg GB, Smith RA, Grant FJ, Biggs S, Bensch PA, Kuijper JL, Sheppard PO and Sprecher CA et al.. (1993) Expression cloning and signaling properties of the rat glucagon receptor. Science 259: 1614-6 [PMID:8384375]

124. Jensen RT and Gardner JD. (1980) Interaction of cholecystokinin with specific membrane receptors on pancreatic acinar cells. Proc Natl Acad Sci USA 77: 2079-2083 [PMID:6246521]

125. Jiang S and Ulrich C. (1995) Molecular cloning and functional expression of a human pancreatic secretin receptor. Biochem Biophys Res Commun 207: 883-90 [PMID:7864894]

126. Jorgensen R, Martini L, Schwartz TW and Elling CE. (2005) Characterization of glucagon-like peptide-1 receptor beta-arrestin 2 interaction: a high-affinity receptor phenotype. $\mathrm{Mol}$ Endocrinol 19: 812-23 [PMID:15528268]

127. Kanashiro-Takeuchi RM, Tziomalos K, Takeuchi LM, Treuer AV, Lamirault G, Dulce R, Hurtado M, Song Y, Block NL and Rick F et al.. (2010) Cardioprotective effects of growth hormonereleasing hormone agonist after myocardial infarction. Proc Natl Acad Sci USA 107: 2604-9 [PMID:20133784]

128. Kawai K, Yokota C, Ohashi S, Watanabe Y and Yamashita K. (1995) Evidence that glucagon stimulates insulin secretion through its own receptor in rats. Diabetologia 38: 274-6 [PMID:7758872]

129. Kazda CM, Ding Y, Kelly RP, Garhyan P, Shi C, Lim CN, Fu H, Watson DE, Lewin AJ and Landschulz WH et al.. (2016) Evaluation of Efficacy and Safety of the Glucagon Receptor Antagonist LY2409021 in Patients With Type 2 Diabetes: 12- and 24-Week Phase 2 Studies. Diabetes Care 39: 1241-9 [PMID:26681715]

130. Kelly RP, Garhyan P, Raddad E, Fu H, Lim CN, Prince MJ, Pinaire JA, Loh MT and Deeg MA. (2015) Short-term administration of the glucagon receptor antagonist LY2409021 lowers blood glucose in healthy people and in those with type 2 diabetes. Diabetes Obes Metab 17: 414-22 [PMID:25656305]

131. Kieffer TJ, McIntosh CH and Pederson RA. (1995) Degradation of glucose-dependent insulinotropic polypeptide and truncated glucagon-like peptide 1 in vitro and in vivo by dipeptidyl peptidase IV. Endocrinology 136: 3585-96 [PMID:7628397]

132. Knudsen LB, Nielsen PF, Huusfeldt PO, Johansen NL, Madsen K, Pedersen FZ, Thøgersen H, Wilken M and Agersø H. (2000) Potent derivatives of glucagon-like peptide-1 with 
pharmacokinetic properties suitable for once daily administration. J Med Chem 43: 1664-9 [PMID:10794683]

133. Kostic TS, Tomić M, Andric SA and Stojilkovic SS. (2002) Calcium-independent and cAMPdependent modulation of soluble guanylyl cyclase activity by $\mathrm{G}$ protein-coupled receptors in pituitary cells. J Biol Chem 277: 16412-8 [PMID:11867632]

134. Koth CM, Murray JM, Mukund S, Madjidi A, Minn A, Clarke HJ, Wong T, Chiang V, Luis E and Estevez A et al.. (2012) Molecular basis for negative regulation of the glucagon receptor. Proc Natl Acad Sci USA 109: 14393-8 [PMID:22908259]

135. Kovacs M, Schally AV, Lee EJ, Busto R, Armatis P, Groot K and Varga JL. (2002) Inhibitory effects of antagonistic analogs of GHRH on GH3 pituitary cells overexpressing the human GHRH receptor. J Endocrinol 175: 425-34 [PMID:12429040]

136. Lance VA, Murphy WA, Sueiras-Diaz J and Coy DH. (1984) Super-active analogs of growth hormone-releasing factor (1-29)-amide. Biochem Biophys Res Commun 119: 265-72 [PMID:6231028]

137. Lankat-Buttgereit B and Göke B. (1997) Cloning and characterization of the 5' flanking sequences (promoter region) of the human GLP-1 receptor gene. Peptides 18: 617-24 [PMID:9213353]

138. Lankat-Buttgereit B, Göke R, Fehmann HC, Richter G and Göke B. (1994) Molecular cloning of a cDNA encoding for the GLP-1 receptor expressed in rat lung. Exp Clin Endocrinol 102: 341-7 [PMID:7813606]

139. Larsen PJ, Tang-Christensen M and Jessop DS. (1997) Central administration of glucagon-like peptide-1 activates hypothalamic neuroendocrine neurons in the rat. Endocrinology 138: 444555 [PMID:9322962]

140. Lau J, Bloch P, Schäffer L, Pettersson I, Spetzler J, Kofoed J, Madsen K, Knudsen LB, McGuire J and Steensgaard DB et al.. (2015) Discovery of the Once-Weekly Glucagon-Like Peptide-1 (GLP1) Analogue Semaglutide. J Med Chem 58: 7370-80 [PMID:26308095]

141. Lee SM, Chen L, Chow BK and Yung WH. (2005) Endogenous release and multiple actions of secretin in the rat cerebellum. Neuroscience 134: 377-86 [PMID:15963647]

142. Lefebvre P. (1966) The physiological effect of glucagon on fat mobilization. Diabetologia 2: 130132 [PMID:6005201]

143. Li B, Xi X, Roane DS, Ryan DH and Martin RJ. (2003) Distribution of glucokinase, glucose transporter GLUT2, sulfonylurea receptor-1, glucagon-like peptide-1 receptor and neuropeptide Y messenger RNAs in rat brain by quantitative real time RT-PCR. Brain Res Mol Brain Res 113: 139-42 [PMID:12750016]

144. Lin C, Lin SC, Chang CP and Rosenfeld MG. (1992) Pit-1-dependent expression of the receptor for growth hormone releasing factor mediates pituitary cell growth. Nature 360: 765-8 [PMID:1334535]

145. Lin SC, Lin CR, Gukovsky I, Lusis AJ, Sawchenko PE and Rosenfeld MG. (1993) Molecular basis of the little mouse phenotype and implications for cell type-specific growth. Nature 364: 208-13 [PMID:8391647]

146. Ling N, Baird A, Wehrenberg WB, Ueno N, Munegumi T and Brazeau P. (1984) Synthesis and in vitro bioactivity of C-terminal deleted analogs of human growth hormone-releasing factor. Biochem Biophys Res Commun 123: 854-61 [PMID:6435620]

147. Ling N, Esch F, Böhlen P, Brazeau P, Wehrenberg WB and Guillemin R. (1984) Isolation, primary structure, and synthesis of human hypothalamic somatocrinin: growth hormonereleasing factor. Proc Natl Acad Sci USA 81: 4302-6 [PMID:6431406]

148. Lok S, Kuijper JL, Jelinek LJ, Kramer JM, Whitmore TE, Sprecher CA, Mathewes S, Grant FJ, Biggs SH and Rosenberg GB et al.. (1994) The human glucagon receptor encoding gene: structure, cDNA sequence and chromosomal localization. Gene 140: 203-9 [PMID:8144028]

149. Lovshin J, Yusta B, Iliopoulos I, Migirdicyan A, Dableh L, Brubaker PL and Drucker DJ. (2000) Ontogeny of the glucagon-like peptide-2 receptor axis in the developing rat intestine. Endocrinology 141: 4194-201 [PMID:11089553]

150. Lu M, Wheeler MB, Leng XH and Boyd 3rd AE. (1993) The role of the free cytosolic calcium level in beta-cell signal transduction by gastric inhibitory polypeptide and glucagon-like peptide I(7-37). Endocrinology 132: 94-100 [PMID:8380389]

151. Lussier BT, French MB, Moore BC and Kraicer J. (1991) Free intracellular Ca2+ concentration $([\mathrm{Ca} 2+] \mathrm{i})$ and growth hormone release from purified rat somatotrophs. I. GH-releasing factorinduced Ca2+ influx raises [Ca2+]i. Endocrinology 128: 570-82 [PMID:1846113]

152. MacLusky NJ, Cook S, Scrocchi L, Shin J, Kim J, Vaccarino F, Asa SL and Drucker DJ. (2000) Neuroendocrine function and response to stress in mice with complete disruption of glucagonlike peptide-1 receptor signaling. Endocrinology 141: 752-62 [PMID:10650957]

153. MacNeil DJ, Occi JL, Hey PJ, Strader CD and Graziano MP. (1994) Cloning and expression of a human glucagon receptor. Biochem Biophys Res Commun 198: 328-34 [PMID:7507321]

154. Madsen P, Knudsen LB, Wiberg FC and Carr RD. (1998) Discovery and structure-activity relationship of the first non-peptide competitive human glucagon receptor antagonists. J Med 
Chem 41: 5150-7 [PMID:9857085]

155. Margioris AN, Brockmann G, Bohler Jr HC, Grino M, Vamvakopoulos N and Chrousos GP. (1990) Expression and localization of growth hormone-releasing hormone messenger ribonucleic acid in rat placenta: in vitro secretion and regulation of its peptide product. Endocrinology 126: 1518 [PMID:2104584]

156. Mark HF and Chow BK. (1995) Localization of the gene encoding the secretin receptor, SCTR, on human chromosome 2q14.1 by fluorescence in situ hybridization and chromosome morphometry. Genomics 29: 817-8 [PMID:8575789]

157. Matsubara S, Sato M, Mizobuchi M, Niimi M and Takahara J. (1995) Differential gene expression of growth hormone $(\mathrm{GH})$-releasing hormone $(\mathrm{GRH})$ and $\mathrm{GRH}$ receptor in various rat tissues. Endocrinology 136: 4147-50 [PMID:7649123]

158. Mayo KE. (1992) Molecular cloning and expression of a pituitary-specific receptor for growth hormone-releasing hormone. Mol Endocrinol 6: 1734-44 [PMID:1333056]

159. Mayo KE, Cerelli GM, Rosenfeld MG and Evans RM. (1985) Characterization of cDNA and genomic clones encoding the precursor to rat hypothalamic growth hormone-releasing factor. Nature 314: 464-7 [PMID:3920534]

160. Mayo KE and Godfrey PA. (1996) The growth-hormone-releasing hormone receptor: signal transduction, gene expression, and physiological function in growth regulation. Ann NY Acad Sci 805: 184-203 [PMID:8993403]

161. Mayo KE, Godfrey PA, Suhr ST, Kulik DJ and Rahal JO. (1995) Growth hormone-releasing hormone: synthesis and signaling. Recent Prog Horm Res 50: 35-73 [PMID:7740167]

162. Mayo KE, Miller LJ, Bataille D, Dalle S, Göke B, Thorens B and Drucker DJ. (2003) International Union of Pharmacology. XXXV. The glucagon receptor family. Pharmacol Rev 55: 167-94 [PMID:12615957]

163. Mayo KE, Vale W, Rivier J, Rosenfeld MG and Evans RM. (1983) Expression-cloning and sequence of a cDNA encoding human growth hormone-releasing factor. Nature 306: 86-8 [PMID:6415488]

164. McIntosh CH, Bremsak I, Lynn FC, Gill R, Hinke SA, Gelling R, Nian C, McKnight G, Jaspers S and Pederson RA. (1999) Glucose-dependent insulinotropic polypeptide stimulation of lipolysis in differentiated 3T3-L1 cells: wortmannin-sensitive inhibition by insulin. Endocrinology 140: 398-404 [PMID:9886851]

165. McKeage K. (2015) Teduglutide: a guide to its use in short bowel syndrome. Clin Drug Investig 35: 335-40 [PMID:25859983]

166. Menzel S, Stoffel M, Espinosa 3rd R, Fernald AA, Le Beau MM and Bell GI. (1994) Localization of the glucagon receptor gene to human chromosome band 17q25. Genomics 20: 327-8 [PMID:8020989]

167. Merchenthaler I, Vigh S, Schally AV and Petrusz P. (1984) Immunocytochemical localization of growth hormone-releasing factor in the rat hypothalamus. Endocrinology 114: 1082-5 [PMID:6423368]

168. Miller TL, Godfrey PA, Dealmeida VI and Mayo KE. (1999) The rat growth hormone-releasing hormone receptor gene: structure, regulation, and generation of receptor isoforms with different signaling properties. Endocrinology 140: 4152-65 [PMID:10465288]

169. Miranda LP, Winters KA, Gegg CV, Patel A, Aral J, Long J, Zhang J, Diamond S, Guido M and Stanislaus S et al.. (2008) Design and synthesis of conformationally constrained glucagon-like peptide-1 derivatives with increased plasma stability and prolonged in vivo activity. J Med Chem 51: 2758-65 [PMID:18412318]

170. Mitchell ML, Byrne MJ and Silver J. (1969) Growth-hormone release by glucagon. Lancet 1: 28990 [PMID:4178983]

171. Miyawaki K, Yamada Y, Yano H, Niwa H, Ban N, Ihara Y, Kubota A, Fujimoto S, Kajikawa M and Kuroe A et al.. (1999) Glucose intolerance caused by a defect in the entero-insular axis: a study in gastric inhibitory polypeptide receptor knockout mice. Proc Natl Acad Sci USA 96: 14843-7 [PMID:10611300]

172. Moens K, Heimberg H, Flamez D, Huypens P, Quartier E, Ling Z, Pipeleers D, Gremlich S, Thorens B and Schuit F. (1996) Expression and functional activity of glucagon, glucagon-like peptide I, and glucose-dependent insulinotropic peptide receptors in rat pancreatic islet cells. Diabetes 45: 257-61 [PMID:8549871]

173. Montrose-Rafizadeh C, Yang H, Rodgers BD, Beday A, Pritchette LA and Eng J. (1997) High potency antagonists of the pancreatic glucagon-like peptide-1 receptor. J Biol Chem 272: 212016 [PMID:9261127]

174. Montrose-Rafizadeh C, Yang H, Wang Y, Roth J, Montrose MH and Adams LG. (1997) Novel signal transduction and peptide specificity of glucagon-like peptide receptor in 3T3-L1 adipocytes. J Cell Physiol 172: 275-83 [PMID:9284947]

175. Moore MC, Connolly CC and Cherrington AD. (1998) Autoregulation of hepatic glucose production. Eur J Endocrinol 138: 240-8 [PMID:9539293]

176. Motomura T, Hashimoto K, Koga M, Arita N, Hayakawa T, Kishimoto T and Kasayama S. (1998) 
Inhibition of signal transduction by a splice variant of the growth hormone-releasing hormone receptor expressed in human pituitary adenomas. Metab Clin Exp 47: 804-8 [PMID:9667225]

177. Munroe DG, Gupta AK, Kooshesh F, Vyas TB, Rizkalla G, Wang H, Demchyshyn L, Yang ZJ, Kamboj RK and Chen H et al.. (1999) Prototypic G protein-coupled receptor for the intestinotrophic factor glucagon-like peptide 2. Proc Natl Acad Sci USA 96: 1569-73 [PMID:9990065]

178. Mutt V, Jorpes JE and Magnusson S. (1970) Structure of porcine secretin. The amino acid sequence. Eur J Biochem 15: 513-9 [PMID:5465996]

179. Mühlhauser I, Koch J and Berger M. (1985) Pharmacokinetics and bioavailability of injected glucagon: differences between intramuscular, subcutaneous, and intravenous administration. Diabetes Care 8: 39-42 [PMID:3971846]

180. Netchine I, Talon P, Dastot F, Vitaux F, Goossens M and Amselem S. (1998) Extensive phenotypic analysis of a family with growth hormone (GH) deficiency caused by a mutation in the GH-releasing hormone receptor gene. J Clin Endocrinol Metab 83: 432-6 [PMID:9467553]

181. Ng SS, Pang RT, Chow BK and Cheng CH. (1999) Real-time evaluation of human secretin receptor activity using cytosensor microphysiometry. J Cell Biochem 72: 517-27 [PMID:10022611]

182. Nilsson A, Carlquist M, Jörnvall H and Mutt V. (1980) Isolation and characterization of chicken secretin. Eur J Biochem 112: 383-8 [PMID:7460928]

183. Nolte WM, Fortin JP, Stevens BD, Aspnes GE, Griffith DA, Hoth LR, Ruggeri RB, Mathiowetz AM, Limberakis C and Hepworth D et al.. (2014) A potentiator of orthosteric ligand activity at GLP-1R acts via covalent modification. Nat Chem Biol 10: 629-31 [PMID:24997604]

184. Northup JK, Smigel MD, Sternweis PC and Gilman AG. (1983) The subunits of the stimulatory regulatory component of adenylate cyclase. Resolution of the activated 45,000-dalton (alpha) subunit. J Biol Chem 258: 11369-11376 [PMID:6309844]

185. Nyström T, Gonon AT, Sjöholm A and Pernow J. (2005) Glucagon-like peptide-1 relaxes rat conduit arteries via an endothelium-independent mechanism. Regul Pept 125: 173-7 [PMID:15582729]

186. Ohlsson L and Lindström P. (1990) The correlation between calcium outflow and growth hormone release in perifused rat somatotrophs. Endocrinology 126: 488-97 [PMID:1688413]

187. Okamoto H, Kim J, Aglione J, Lee J, Cavino K, Na E, Rafique A, Kim JH, Harp J and Valenzuela DM et al.. (2015) Glucagon Receptor Blockade With a Human Antibody Normalizes Blood Glucose in Diabetic Mice and Monkeys. Endocrinology 156: 2781-94 [PMID:26020795]

188. Parker JC, Andrews KM, Allen MR, Stock JL and McNeish JD. (2002) Glycemic control in mice with targeted disruption of the glucagon receptor gene. Biochem Biophys Res Commun 290: 839-843 [PMID:11785978]

189. Parthier C, Kleinschmidt M, Neumann P, Rudolph R, Manhart S, Schlenzig D, Fanghänel J, Rahfeld JU, Demuth HU and Stubbs MT. (2007) Crystal structure of the incretin-bound extracellular domain of a G protein-coupled receptor. Proc Natl Acad Sci USA 104: 13942-7 [PMID:17715056]

190. Petersen KF and Sullivan JT. (2001) Effects of a novel glucagon receptor antagonist (Bay 279955) on glucagon-stimulated glucose production in humans. Diabetologia 44: 2018-24 [PMID:11719833]

191. Petersenn S, Rasch AC, Heyens M and Schulte HM. (1998) Structure and regulation of the human growth hormone-releasing hormone receptor gene. Mol Endocrinol 12: 233-47 [PMID:9482665]

192. Pohl SL, Birnbaumer L and Rodbell M. (1969) Glucagon-sensitive adenyl cylase in plasma membrane of hepatic parenchymal cells. Science 164: 566-7 [PMID:4305077]

193. Pohl SL, Birnbaumer L and Rodbell M. (1971) The glucagon-sensitive adenyl cyclase system in plasma membranes of rat liver. I. Properties. J Biol Chem 246: 1849-56 [PMID:4993961]

194. Preitner F, Ibberson M, Franklin I, Binnert C, Pende M, Gjinovci A, Hansotia T, Drucker DJ, Wollheim C and Burcelin R et al.. (2004) Gluco-incretins control insulin secretion at multiple levels as revealed in mice lacking GLP-1 and GIP receptors. J Clin Invest 113: 635-45 [PMID:14966573]

195. Qureshi SA, Rios Candelore M, Xie D, Yang X, Tota LM, Ding VD, Li Z, Bansal A, Miller C and Cohen SM et al.. (2004) A novel glucagon receptor antagonist inhibits glucagon-mediated biological effects. Diabetes 53: 3267-73 [PMID:15561959]

196. Ramírez JL, Castaño JP, Torronteras R, Martínez-Fuentes AJ, Frawley LS, García-Navarro S and Gracia-Navarro F. (1999) Growth hormone (GH)-releasing factor differentially activates cyclic adenosine $3^{\prime}, 5^{\prime}$-monophosphate- and inositol phosphate-dependent pathways to stimulate GH release in two porcine somatotrope subpopulations. Endocrinology 140: 1752-9 [PMID:10098512]

197. Raufman JP, Singh L and Eng J. (1991) Exendin-3, a novel peptide from Heloderma horridum venom, interacts with vasoactive intestinal peptide receptors and a newly described receptor on dispersed acini from guinea pig pancreas. Description of exendin-3(9-39) amide, a specific 
exendin receptor antagonist. J Biol Chem 266: 2897-902 [PMID:1704369]

198. Richter G, Göke R, Göke B and Arnold R. (1990) Characterization of receptors for glucagon-like peptide-1(7-36)amide on rat lung membranes. FEBS Lett 267: 78-80 [PMID:2163902]

199. Richter G, Göke R, Göke B, Schmidt H and Arnold R. (1991) Characterization of glucagon-like peptide-I(7-36)amide receptors of rat lung membranes by covalent cross-linking. FEBS Lett 280: 247-50 [PMID:1849486]

200. Rivier J and Vale W. (1982) Characterization of a growth hormone-releasing factor from a human pancreatic islet tumour. Nature 300: 276-278 [PMID:6292724]

201. Robberecht P, Coy DH, Waelbroeck M, Heiman ML, de Neef P, Camus JC and Christophe J. (1985) Structural requirements for the activation of rat anterior pituitary adenylate cyclase by growth hormone-releasing factor (GRF): discovery of (N-Ac-Tyr1, D-Arg2)-GRF(1-29)-NH2 as a GRF antagonist on membranes. Endocrinology 117: 1759-64 [PMID:2994998]

202. Robberecht P, De Neef P, Waelbroeck M, Camus JC, Scemama JL, Fourmy D, Pradayrol L, Vaysse N and Christophe J. (1988) Secretin receptors in human pancreatic membranes. Pancreas 3: 529-35 [PMID:3186683]

203. Runge S, Thøgersen H, Madsen K, Lau J and Rudolph R. (2008) Crystal structure of the ligandbound glucagon-like peptide-1 receptor extracellular domain. J Biol Chem 283: 11340-7 [PMID:18287102]

204. Salvatori R, Hayashida CY, Aguiar-Oliveira MH, Phillips 3rd JA, Souza AH, Gondo RG, Toledo SP, Conceicão MM, Prince M and Maheshwari HG et al.. (1999) Familial dwarfism due to a novel mutation of the growth hormone-releasing hormone receptor gene. J Clin Endocrinol Metab 84: 917-23 [PMID:10084571]

205. Samols E, Marri G and Marks V. (1966) Interrelationship of glucagon, insulin and glucose. The insulinogenic effect of glucagon. Diabetes 15: 855-66 [PMID:5957476]

206. Sawchenko PE, Swanson LW, Rivier J and Vale WW. (1985) The distribution of growth-hormonereleasing factor (GRF) immunoreactivity in the central nervous system of the rat: an immunohistochemical study using antisera directed against rat hypothalamic GRF. J Comp Neurol 237: 100-15 [PMID:3930577]

207. Schaffalitzky de Muckadell OB and Fahrenkrug J. (1978) Secretion pattern of secretin in man: regulation by gastric acid. Gut 19: 812-8 [PMID:30682]

208. Schally AV and Varga JL. (1999) Antagonistic Analogs of Growth Hormone-releasing Hormone: New Potential Antitumor Agents. Trends Endocrinol Metab 10: 383-391 [PMID:10542394]

209. Schirra J, Kuwert P, Wank U, Leicht P, Arnold R, Göke B and Katschinski M. (1997) Differential effects of subcutaneous GLP-1 on gastric emptying, antroduodenal motility, and pancreatic function in men. Proc Assoc Am Physicians 109: 84-97 [PMID:9010920]

210. Schmidtler J, Dehne K, Offermanns S, Rosenthal W, Classen M and Schepp W. (1994) Stimulation of rat parietal cell function by histamine and GLP-1-(7-36) amide is mediated by Gs alpha. Am J Physiol 266: G775-82 [PMID:8203524]

211. Scott RB, Kirk D, MacNaughton WK and Meddings JB. (1998) GLP-2 augments the adaptive response to massive intestinal resection in rat. Am J Physiol 275: G911-21 [PMID:9815019]

212. Shimizu I, Hirota M, Ohboshi C and Shima K. (1987) Identification and localization of glucagonlike peptide-1 and its receptor in rat brain. Endocrinology 121: 1076-82 [PMID:3040376]

213. Shinomura Y, Eng J and Yalow RS. (1987) Dog secretin: sequence and biologic activity. Life Sci 41: 1243-8 [PMID:3626755]

214. Shughrue PJ, Lane MV and Merchenthaler I. (1996) Glucagon-like peptide-1 receptor (GLP1-R) mRNA in the rat hypothalamus. Endocrinology 137: 5159-62 [PMID:8895391]

215. Siani A, Iacone R, Russo O, Barba G, Russo P, Cappuccio FP, Galletti F and Strazzullo P. (2001) Gly40Ser polymorphism of the glucagon receptor gene is associated with central adiposity in men. Obes Res 9: 722-6 [PMID:11707539]

216. Siu FY, He M, de Graaf C, Han GW, Yang D, Zhang Z, Zhou C, Xu Q, Wacker D and Joseph JS et al.. (2013) Structure of the human glucagon class B G-protein-coupled receptor. Nature 499: 444-9 [PMID:23863937]

217. Skoglund G, Hussain MA and Holz GG. (2000) Glucagon-like peptide 1 stimulates insulin gene promoter activity by protein kinase A-independent activation of the rat insulin I gene cAMP response element. Diabetes 49: 1156-1164 [PMID:10909973]

218. Slim GM, Lansing M, Wizzard P, Nation PN, Wheeler SE, Brubaker PL, Jeppesen PB, Wales PW and Turner JM. (2019) Novel Long-Acting GLP-2 Analogue, FE 203799 (Apraglutide), Enhances Adaptation and Linear Intestinal Growth in a Neonatal Piglet Model of Short Bowel Syndrome with Total Resection of the Ileum. JPEN J Parenter Enteral Nutr 43: 891-898 [PMID:30614011]

219. Song G, Yang D, Wang Y, de Graaf C, Zhou Q, Jiang S, Liu K, Cai X, Dai A and Lin G et al.. (2017) Human GLP-1 receptor transmembrane domain structure in complex with allosteric modulators. Nature 546: 312-315 [PMID:28514449]

220. Spiess J, Rivier J and Vale W. (1983) Characterization of rat hypothalamic growth hormonereleasing factor. Nature 303: 532-5 [PMID:6406907]

221. Stefaneanu L, Kovacs K, Horvath E, Asa SL, Losinski NE, Billestrup N, Price J and Vale W. 
(1989) Adenohypophysial changes in mice transgenic for human growth hormone-releasing factor: a histological, immunocytochemical, and electron microscopic investigation.

Endocrinology 125: 2710-8 [PMID:2507296]

222. Stephanou A, Knight RA and Lightman SL. (1991) Production of a growth hormone-releasing hormone-like peptide and its mRNA by human lymphocytes. Neuroendocrinology 53: 628-33 [PMID:1876239]

223. Stoffel M, Espinosa 3rd R, Le Beau MM and Bell GI. (1993) Human glucagon-like peptide-1 receptor gene. Localization to chromosome band $6 \mathrm{p} 21$ by fluorescence in situ hybridization and linkage of a highly polymorphic simple tandem repeat DNA polymorphism to other markers on chromosome 6. Diabetes 42: 1215-8 [PMID:8392011]

224. Suhr ST, Rahal JO and Mayo KE. (1989) Mouse growth-hormone-releasing hormone: precursor structure and expression in brain and placenta. Mol Endocrinol 3: 1693-700 [PMID:2514346]

225. Svoboda M and Christophe J. (1993) A cDNA construct allowing the expression of rat hepatic glucagon receptors. Biochem Biophys Res Commun 192: 135-142 [PMID:8386505]

226. Szpirer C, Szpirer J, Vanvooren P, Rivière M, Maget B, Svoboda M, Shiozawa M, Simon JS, Jacob HJ and Koike G. (1997) Localization of the rat genes encoding glucagon, glucagon receptor, and insulin receptor, candidates for diabetes mellitus susceptibility loci. Mamm Genome 8: 586-8 [PMID:9250867]

227. Takahashi $\mathrm{T}$ and Chihara K. (1995) Regional distribution of growth hormone-releasing hormone (GHRH) receptor mRNA in the rat brain. Endocrinology 136: 4721-4724 [PMID:7664697]

228. Takano K, Takei T, Teramoto A and Yamashita N. (1996) GHRH activates a nonselective cation current in human GH-secreting adenoma cells. Am J Physiol 270: E1050-7 [PMID:8764191]

229. Tang J, Lagacé G, Castagné J and Collu R. (1995) Identification of human growth hormonereleasing hormone receptor splicing variants. J Clin Endocrinol Metab 80: 2381-7 [PMID:7629234]

230. Tay J, Goulet M, Rusche J and Boismenu R. (2004) Age-related and regional differences in secretin and secretin receptor mRNA levels in the rat brain. Neurosci Lett 366: 176-81 [PMID:15276242]

231. Thorens B. (1992) Expression cloning of the pancreatic beta cell receptor for the gluco-incretin hormone glucagon-like peptide 1. Proc Natl Acad Sci USA 89: 8641-5 [PMID:1326760]

232. Thorens B, Porret A, Bühler L, Deng SP, Morel P and Widmann C. (1993) Cloning and functional expression of the human islet GLP-1 receptor. Demonstration that exendin-4 is an agonist and exendin-(9-39) an antagonist of the receptor. Diabetes 42: 1678-82 [PMID:8405712]

233. Thorens B and Widmann C. (1996) Structure and function of the glucagon-like peptide-1 receptor. In Handbook of Experimental Pharmacology Glucagon III Edited by Lefebvre PJ: Springer: 255-273 [ISBN: 354060989X]

234. Thulesen J, Knudsen LB, Hartmann B, Hastrup S, Kissow H, Jeppesen PB, Ørskov C, Holst JJ and Poulsen SS. (2002) The truncated metabolite GLP-2 (3-33) interacts with the GLP-2 receptor as a partial agonist. Regul Pept 103: 9-15 [PMID:11738243]

235. Tibaduiza EC, Chen C and Beinborn M. (2001) A small molecule ligand of the glucagon-like peptide 1 receptor targets its amino-terminal hormone binding domain. J Biol Chem 276: 3778793 [PMID:11498540]

236. Trümper A, Trümper K, Trusheim H, Arnold R, Göke B and Hörsch D. (2001) Glucose-dependent insulinotropic polypeptide is a growth factor for beta (INS-1) cells by pleiotropic signaling. $\mathrm{Mol}$ Endocrinol 15: 1559-70 [PMID:11518806]

237. Tsai CH, Hill M, Asa SL, Brubaker PL and Drucker DJ. (1997) Intestinal growth-promoting properties of glucagon-like peptide-2 in mice. Am J Physiol 273: E77-84 [PMID:9252482]

238. Tsai CH, Hill M and Drucker DJ. (1997) Biological determinants of intestinotrophic properties of GLP-2 in vivo. Am J Physiol 272: G662-8 [PMID:9124589]

239. Tseng CC, Kieffer TJ, Jarboe LA, Usdin TB and Wolfe MM. (1996) Postprandial stimulation of insulin release by glucose-dependent insulinotropic polypeptide (GIP). Effect of a specific glucose-dependent insulinotropic polypeptide receptor antagonist in the rat. J Clin Invest 98: 2440-5 [PMID:8958204]

240. Tseng CC, Zhang XY and Wolfe MM. (1999) Effect of GIP and GLP-1 antagonists on insulin release in the rat. Am J Physiol 276: E1049-54 [PMID:10362617]

241. Turton MD, O'Shea D, Gunn I, Beak SA, Edwards CM, Meeran K, Choi SJ, Taylor GM, Heath MM and Lambert PD et al.. (1996) A role for glucagon-like peptide-1 in the central regulation of feeding. Nature 379: 69-72 [PMID:8538742]

242. Ulrich 2nd CD, Wood P, Hadac EM, Kopras E, Whitcomb DC and Miller LJ. (1998) Cellular distribution of secretin receptor expression in rat pancreas. Am J Physiol 275: G1437-44 [PMID:9843782]

243. Unson CG, Andreu D, Gurzenda EM and Merrifield RB. (1987) Synthetic peptide antagonists of glucagon. Proc Natl Acad Sci USA 84: 4083-7 [PMID:3035568]

244. Unson CG, Gurzenda EM and Merrifield RB. (1989) Biological activities of desHis1[Glu9]glucagon amide, a glucagon antagonist. Peptides 10: 1171-7 [PMID:2560175] 
245. Usdin TB and Bonner TI. (1993) Gastric inhibitory polypeptide receptor, a member of the secretin- vasoactive intestinal peptide receptor family, is widely distributed in peripheral organs and the brain. Endocrinology 133: 2861-2870 [PMID:8243312]

246. Uttenthal LO and Blázquez E. (1990) Characterization of high-affinity receptors for truncated glucagon-like peptide-1 in rat gastric glands. FEBS Lett 262: 139-41 [PMID:2156728]

247. Uttenthal LO, Toledano A and Blázquez E. (1992) Autoradiographic localization of receptors for glucagon-like peptide-1 (7-36) amide in rat brain. Neuropeptides 21: 143-6 [PMID:1352862]

248. Valverde I, Mérida E, Delgado E, Trapote MA and Villanueva-Peñacarrillo ML. (1993) Presence and characterization of glucagon-like peptide-1(7-36) amide receptors in solubilized membranes of rat adipose tissue. Endocrinology 132: 75-9 [PMID:8380388]

249. van Eyll B, Lankat-Buttgereit B, Bode HP, Göke R and Göke B. (1994) Signal transduction of the GLP-1-receptor cloned from a human insulinoma. FEBS Lett 348: 7-13 [PMID:7517895]

250. Varga JL, Schally AV, Csernus VJ, Zarándi M, Halmos G, Groot K and Rékási Z. (1999) Synthesis and biological evaluation of antagonists of growth hormone-releasing hormone with high and protracted in vivo activities. Proc Natl Acad Sci USA 96: 692-7 [PMID:9892695]

251. Varga JL, Schally AV, Horvath JE, Kovacs M, Halmos G, Groot K, Toller GL, Rekasi Z and Zarandi M. (2004) Increased activity of antagonists of growth hormone-releasing hormone substituted at positions 8, 9, and 10. Proc Natl Acad Sci USA 101: 1708-13 [PMID:14755056]

252. Volz A, Göke R, Lankat-Buttgereit B, Fehmann HC, Bode HP and Göke B. (1995) Molecular cloning, functional expression, and signal transduction of the GIP-receptor cloned from a human insulinoma. FEBS Lett 373: 23-9 [PMID:7589426]

253. Wajnrajch MP, Chua SC, Green ED and Leibel RL. (1994) Human growth hormone-releasing hormone receptor (GHRHR) maps to a YAC at chromosome 7p15. Mamm Genome 5: 595 [PMID:8000149]

254. Wajnrajch MP, Gertner JM, Harbison MD, Chua Jr SC and Leibel RL. (1996) Nonsense mutation in the human growth hormone-releasing hormone receptor causes growth failure analogous to the little (lit) mouse. Nat Genet 12: 88-90 [PMID:8528260]

255. Wakelam MJ, Murphy GJ, Hruby VJ and Houslay MD. (1986) Activation of two signaltransduction systems in hepatocytes by glucagon. Nature 323: 68-71 [PMID:3018586]

256. Walsh NA, Yusta B, DaCambra MP, Anini Y, Drucker DJ and Brubaker PL. (2003) Glucagon-like peptide-2 receptor activation in the rat intestinal mucosa. Endocrinology 144: 4385-92 [PMID:12960094]

257. Wei Y and Mojsov S. (1995) Tissue-specific expression of the human receptor for glucagon-like peptide-I: brain, heart and pancreatic forms have the same deduced amino acid sequences. FEBS Lett 358: 219-24 [PMID:7843404]

258. Werner U, Haschke G, Herling AW and Kramer W. (2010) Pharmacological profile of lixisenatide: A new GLP-1 receptor agonist for the treatment of type 2 diabetes. Regul Pept 164: 58-64 [PMID:20570597]

259. Wheeler MB, Gelling RW, McIntosh CH, Georgiou J, Brown JC and Pederson RA. (1995) Functional expression of the rat pancreatic islet glucose-dependent insulinotropic polypeptide receptor: ligand binding and intracellular signaling properties. Endocrinology 136: 4629-39 [PMID:7664683]

260. Wheeler MB, Lu M, Dillon JS, Leng XH, Chen C and Boyd 3rd AE. (1993) Functional expression of the rat glucagon-like peptide-I receptor, evidence for coupling to both adenylyl cyclase and phospholipase-C. Endocrinology 133: 57-62 [PMID:8391428]

261. White CM. (1999) A review of potential cardiovascular uses of intravenous glucagon administration. J Clin Pharmacol 39: 442-7 [PMID:10234590]

262. Widmann C, Dolci W and Thorens B. (1997) Internalization and homologous desensitization of the GLP-1 receptor depend on phosphorylation of the receptor carboxyl tail at the same three sites. Mol Endocrinol 11: 1094-102 [PMID:9212057]

263. Wildhage I, Trusheim H, Göke B and Lankat-Buttgereit B. (1999) Gene expression of the human glucagon-like peptide-1 receptor is regulated by Sp1 and Sp3. Endocrinology 140: 624-31 [PMID:9927286]

264. Wiśniewski K, Sueiras-Diaz J, Jiang G, Galyean R, Lu M, Thompson D, Wang YC, Croston G, Posch A and Hargrove DM et al.. (2016) Synthesis and Pharmacological Characterization of Novel Glucagon-like Peptide-2 (GLP-2) Analogues with Low Systemic Clearance. J Med Chem 59: 3129-39 [PMID:26986178]

265. Wright DE, Hruby VJ and Rodbell M. (1978) A reassessment of structure-function relationships in glucagon. Glucagon1-21 is a full agonist. J Biol Chem 253: 6338-40 [PMID:210180]

266. Wright DE and Rodbell M. (1979) Glucagon1-6 binds to the glucagon receptor and activates hepatic adenylate cyclase. J Biol Chem 254: 268-269 [PMID:216670]

267. Xiong X, Ke X, Wang L, Yao Z, Guo Y, Zhang X, Chen Y, Pang CP, Schally AV and Zhang H. (2020) Splice variant of growth hormone-releasing hormone receptor drives esophageal squamous cell carcinoma conferring a therapeutic target. Proc Natl Acad Sci USA 117: 67266732 [PMID:32156725] 
268. Xiong Y, Guo J, Candelore MR, Liang R, Miller C, Dallas-Yang Q, Jiang G, McCann PE, Qureshi SA and Tong X et al.. (2012) Discovery of a novel glucagon receptor antagonist N-[(4- $\{(1 \mathrm{~S})-1-[3-$ (3, 5-dichlorophenyl)-5-(6-methoxynaphthalen-2-yl)-1H-pyrazol-1-yl]ethyl $\}$ phenyl)carbonyl]- $\beta$ alanine (MK-0893) for the treatment of type II diabetes. J Med Chem 55: 6137-48 [PMID:22708876]

269. Yada T and Nakata M. (1993) Glucagon-like peptide-1-(7-36)amide and a rise in cyclic adenosine 3', 5'-monophosphate increase cytosolic free $\mathrm{Ca}^{2+}$ in rat pancreatic $\beta$-cells by enhancing $\mathrm{Ca}^{2+}$ channel activity. Endocrinology 133: 1685-1692 [PMID:8404610]

270. Yang PY, Zou H, Lee C, Muppidi A, Chao E, Fu Q, Luo X, Wang D, Schultz PG and Shen W. (2018) Stapled, Long-Acting Glucagon-like Peptide 2 Analog with Efficacy in Dextran Sodium Sulfate Induced Mouse Colitis Models. J Med Chem 61: 3218-3223 [PMID:29528634]

271. You CH, Rominger JM and Chey WY. (1983) Potentiation effect of cholecystokinin-octapeptide on pancreatic bicarbonate secretion stimulated by a physiologic dose of secretin in humans. Gastroenterology 85: 40-5 [PMID:6303892]

272. Yusta B, Somwar R, Wang F, Munroe D, Grinstein S, Klip A and Drucker DJ. (1999) Identification of glucagon-like peptide-2 (GLP-2)-activated signaling pathways in baby hamster kidney fibroblasts expressing the rat GLP-2 receptor. J Biol Chem 274: 30459-67 [PMID:10521425]

273. Zarandi M, Horvath JE, Halmos G, Pinski J, Nagy A, Groot K, Rekasi Z and Schally AV. (1994) Synthesis and biological activities of highly potent antagonists of growth hormone-releasing hormone. Proc Natl Acad Sci USA 91: 12298-302 [PMID:7991622]

274. Zarandi M, Kovacs M, Horvath JE, Toth K, Halmos G, Groot K, Nagy A, Kele Z and Schally AV. (1997) Synthesis and in vitro evaluation of new potent antagonists of growth hormone-releasing hormone (GH-RH). Peptides 18: 423-430 [PMID:9145431]

275. Zeitler P, Stevens P and Siriwardana G. (1998) Functional GHRH receptor carboxyl terminal isoforms in normal and dwarf (dw) rats. J Mol Endocrinol 21: 363-71 [PMID:9845677]

276. Zhang H, Qiao A, Yang D, Yang L, Dai A, de Graaf C, Reedtz-Runge S, Dharmarajan V, Zhang H and Han GW et al.. (2017) Structure of the full-length glucagon class B G-protein-coupled receptor. Nature 546: 259-264 [PMID:28514451]

277. Zhang H, Qiao A, Yang L, Van Eps N, Frederiksen KS, Yang D, Dai A, Cai X, Zhang H and Yi C et al.. (2018) Structure of the glucagon receptor in complex with a glucagon analogue. Nature 553: 106-110 [PMID:29300013]

278. Zhong Q, Bollag RJ, Dransfield DT, Gasalla-Herraiz J, Ding KH, Min L and Isales CM. (2000) Glucose-dependent insulinotropic peptide signaling pathways in endothelial cells. Peptides 21 : 1427-32 [PMID:11072131] 